\title{
FAKTOR YANG BERHUBUNGAN DENGAN PERILAKU PENGGUNAAN APD PADA PETUGAS LABORATORIUM RUMAH SAKIT PHC SURABAYA
}

\author{
FACTORS RELATED TO BEHAVIOR OF USING PERSONAL \\ PROTECTOR EQUIPMENT ON HOUSEHOLD LABORATORY IN \\ PHC HOSPITAL SURABAYA
}

\author{
Arta Novita Harlan \\ Badan Penyelenggara Jaminan Sosial (BPJS) Kesehatan, Sidoarjo, Jawa Timur \\ E-mail: artanovitaharlan@ymail.com
}

\begin{abstract}
Laboratory workers had high risk of being exposed to biological factors such as HIV/AIDS, HBV, HCV viruses and mycobacterium tuberculosis germ. It was obligatory to protect laboratory workers from all contagious diseases by using Personal Protection Equipment (PPE). This research had done to learn factors related to laboratory workers behavior of PPE usage at PHC Surabaya Hospital. This was a descriptive observational research with cross-sectional design. Sample of this research was total population of all PHC Surabaya Hospital laboratory workers (medical analyst/health analyst) in June 2014. Data were taken by questionnaires, observation and interview. The independent variables were predisposing factors (age, sex, time worked, education level, knowledge and attitude), enabling factor (the availability of PPE), reinforcing factors (regulation/policy, socialization, monitoring and reward and punishment). The dependent variable was behavior of PPE usage. The result of this research was acquired that $53.3 \%$ respondents were $<31$ years, $73.3 \%$ respondents was woman, had time worked about 5-10 years, $80 \%$ respondents had education level diploma, $86.7 \%$ respondent had good knowledge and 53.3\% respondents had good attitude, $60 \%$ respondents stated that the availability of PPE were laboratory coats, gloves, and masks, $86.7 \%$ respondents stated that there was socialization, $73.3 \%$ respondents stated that there was monitoring and $80 \%$ respondents stated that there wasn't punishment. The younger age, the lower time worked, and more complete the availability of PPE, the better the behavior of PPE usage.
\end{abstract}

Keywords: PPE usage, laboratory worker, hospital

\begin{abstract}
ABSTRAK
Petugas laboratorium berisiko terpajan faktor biologi yaitu virus HIV/AIDS, HBV, HCV, dan kuman mycobacterium tuberculosis. Oleh karena itu, diperlukan upaya pengendalian untuk melindungi pekerja dari efek penularan penyakit tersebut, salah satunya dengan penggunaan Alat Pelindung Diri (APD). Penelitian ini dilakukan untuk mempelajari faktor yang berhubungan dengan penggunaan APD pada petugas laboratorium Rumah Sakit PHC Surabaya. Penelitian ini bersifat observational, dan dari sistem analisisnya termasuk penelitian deskriptif dengan pendekatan cross-sectional. Sampel penelitian ini adalah total populasi, yakni semua petugas laboratorium sebagai analis medis/analis kesehatan pada bulan Juni 2014 di Rumah Sakit PHC Surabaya. Data diambil menggunakan kuesioner, observasi dan wawancara. Variabel penelitian adalah faktor predisposisi (usia, jenis kelamin, masa kerja, tingkat pendidikan, pengetahuan dan sikap), faktor pendukung (ketersediaan APD), faktor pendorong (peraturan/kebijakan, sosialisasi, pengawasan, pemberian penghargaan dan sanksi) dan perilaku penggunaan APD. Hasil penelitian diperoleh bahwa 53,3\% responden berusia $<31$ tahun, 73,3\% responden adalah perempuan dengan masa kerja 5-10 tahun, 80\% responden mempunyai tingkat pendidikan diploma, $86,7 \%$ responden berpengetahuan baik dan $53,3 \%$ responden mempunyai sikap baik, $60 \%$ menyatakan bahwa APD yang tersedia adalah jas laboratorium, sarung tangan dan masker (tersedia sebagian), 86,7\% responden menyatakan ada sosialisasi, 73,3\% responden menyatakan ada pengawasan dan $80 \%$ responden menyatakan tidak ada pemberian sanksi. Hanya 40\% responden yang mempunyai perilaku penggunaan APD baik. Semakin muda usia, semakin sedikit masa kerja, semakin lengkap APD yang tersedia maka semakin baik perilaku penggunaan APD.
\end{abstract}

Kata kunci: penggunaan APD, petugas laboratorium, rumah sakit 


\section{PENDAHULUAN}

Rumah sakit sebagaimana tempat kerja pada umumnya mempunyai bahaya potensial yang cukup beragam dalam proses kerjanya. Bahaya potensial tersebut, apabila tidak dikendalikan dengan sebaik mungkin akan berpotensi untuk terjadinya kecelakaan kerja dan penyakit akibat kerja (PAK). Oleh sebab itu, bahaya potensial sebisa mungkin harus diminimalisasir kemungkinan terjadinya, salah satunya melalui upaya Keselamatan dan Kesehatan Kerja (K3).

Pada akhir abad 18, di dunia Internasional, program K3 telah diterapkan di berbagai sektor industri, kecuali sektor kesehatan. Rumah sakit merupakan salah satu bagian dari sektor kesehatan. Perkembangan K3 di rumah sakit (K3RS) dikatakan tertinggal karena sebagian besar fokus kegiatan pada pengobatan (kuratif), bukan pencegahan (preventif). Tenaga kesehatan rumah sakit dianggap telah mempunyai pengetahuan yang memadai sehingga mereka mampu untuk melindungi dirinya dari segala bahaya potensial yang ada pada tempat kerjanya (lampiran Kepmenkes 1087/MENKES/SK/ VIII/ 2010) Dalam Kepmenkes 1087/MENKES/SK/ VIII/2010 juga disebutkan mengenai data dan fakta mengenai K3RS. Berdasarkan data dari World Health Organization (WHO) diketahui bahwa dari 35 juta tenaga kesehatan, 3 juta terpajan patogen darah ( 2 juta terpajan virus HBV, 0,9 juta terpajan HBC dan 170.000 terpajan virus HIV/AIDS). Sebanyak $8-12 \%$ pekerja rumah sakit sensitif terhadap lateks. International Labor Organization (ILO) juga menyebutkan bahwa 108.256 kematian pekerja laki-laki dan 517.404 kematian pekerja perempuan akibat penyakit menular yang berhubungan dengan pekerjaan.

Petugas laboratorium sebagai pekerja salah satu unit pada rumah sakit dengan bahaya potensial yang cukup tinggi juga mempunyai kemungkinan untuk mengalami risiko bahaya tersebut. Kegiatan laboratorium mempunyai risiko yang berasal dari berbagai macam faktor, yakni fisik, kimia, ergonomi dan psikososial. Variasi, ukuran, tipe dan kelengkapan laboratorium juga menentukan kesehatan dan keselamatan kerja. Seiring dengan kemajuan IPTEK, khususnya kemajuan teknologi laboratorium, maka risiko yang dihadapi petugas laboratorium semakin meningkat.

Guna mengatasi risiko dari bahaya tersebut, sepatutnya upaya pengendalian bahaya harus senantiasa dilakukan oleh pengelola tempat kerja sebagaimana yang tercantum dalam Undang-Undang No. 36 tahun 2009 pasal 165:

\section{"Pengelola tempat kerja wajib melakukan segala bentuk upaya kesehatan melalui upaya pencegahan, peningkatan, pengobatan dan pemulihan bagi tenaga kerja".}

Berdasarkan pasal di atas maka manajemen rumah sakit mempunyai kewajiban untuk menyehatkan para tenaga kerjanya. Salah satunya adalah melalui kesehatan kerja di samping keselamatan kerja. Dalam Kepmenkes 1087/ MENKES/SK/VIII/2010 disebutkan juga mengenai program K3RS yang salah satunya adalah pengembangan manajemen tanggap darurat. Dalam program pengembangan manajemen tanggap darurat, salah satu implementasi yang harus dilakukan adalah memberikan APD pada petugas di tempat yang berisiko.

Meski pada dasarnya penggunaan APD terlihat mudah, namun pada penerapannya tidak semua petugas laboratorium, yang notabene mempunyai risiko yang cukup besar, selalu menggunakannya. Berdasarkan hasil penelitian Jannah (2009), diperoleh informasi bahwa sebanyak $66,7 \%$ pekerja laboratorium patologi klinik RSUD Sidoarjo tidak selalu (kadang-kadang) menggunakan APD saat melakukan aktivitas kerjanya. Rahaju (2011) menyebutkan bahwa sebanyak $33,7 \%$ petugas unit pelayanan laboratorium di Kota Bandar Lampung tidak menggunakan APD saat bekerja.

Berdasarkan uraian yang telah disebutkan, diketahui bahwa perilaku penggunaan APD pada petugas laboratorium masih belum optimal dan sebagai imbasnya, risiko yang dimiliki oleh petugas laboratorium pun akan semakin besar. Perilaku yang kurang baik ini dapat disebabkan berbagai macam faktor yang menjadi latar belakang. Oleh karena itu, penulis tertarik untuk melakukan penelitian mengenai "faktor yang berhubungan dengan perilaku penggunaan APD pada petugas laboratorium Rumah Sakit PHC Surabaya".

\section{METODE}

Penelitian ini merupakan penelitian survei (non eksperimental), karena peneliti tidak melakukan intervensi terhadap variabel selama penelitian (Notoatmodjo, 2012). Ditinjau dari sifatnya, penelitian ini termasuk dalam penelitian deskriptif karena berusaha menggambarkan mengenai fakta yang akan diteliti. Berdasarkan pendekatannya, 
penelitian ini merupakan penelitian cross-sectional karena variabel yang diamati dikumpulkan dalam kurun waktu yang bersamaan.

Populasi dalam penelitian ini adalah seluruh petugas laboratorium Rumah Sakit PHC Surabaya yang bekerja sebagai analis medis pada saat penelitian dilakukan (Juni 2014) sejumlah 15 petugas. Adapun sampel penelitian menggunakan total populasi.

Variabel bebas dalam penelitian ini adalah faktor predisposisi (usia, jenis kelamin, masa kerja, tingkat pendidikan, pengetahuan dan sikap), faktor pendukung (ketersediaan APD) dan faktor pendorong (peraturan/kebijakan, sosialisasi, pengawasan, pemberian penghargaan dan pemberian sanksi). Adapun variabel terikat dalam penelitian ini adalah perilaku penggunaan APD.

\section{HASIL}

Petugas laboratorium Rumah Sakit PHC Surabaya yang bekerja sebagai analis medis pada dasarnya sebanyak 17 petugas, namun pada saat penelitian dilakukan 2 petugas lainnya sedang mengikuti pelatihan sehingga sampel yang diperoleh hanya 15 petugas.

Tabel 1. Distribusi Responden Berdasarkan Variabel Faktor Predisposisi Perilaku Penggunaan APD

\begin{tabular}{lcc}
\hline Faktor Predisposisi & $\begin{array}{c}\text { Jumlah } \\
\text { (orang) }\end{array}$ & $\begin{array}{c}\text { Persentase } \\
(\%)\end{array}$ \\
\hline Usia & & \\
$\quad<31$ tahun & 8 & 53,3 \\
$31-40$ tahun & 6 & 40 \\
$\quad>40$ tahun & 1 & 6,7 \\
\hline Jenis Kelamin & & \\
$\quad$ Laki-laki & 4 & 26,7 \\
$\quad$ Perempuan & 11 & 73,3 \\
\hline Masa Kerja & & \\
$\quad<5$ tahun & 5 & 33,3 \\
5-10 tahun & 7 & 46,7 \\
$\quad>10$ tahun & 3 & 20 \\
\hline Tingkat Pendidikan & & \\
$\quad$ Diploma & 12 & 80 \\
$\quad$ Sarjana & 3 & 20 \\
\hline Pengetahuan & & \\
Baik & 13 & 86,7 \\
$\quad$ Cukup & 2 & 13,3 \\
\hline Sikap & & \\
$\quad$ Baik & 8 & 53,3 \\
$\quad$ Cukup & 7 & 46,7 \\
\hline
\end{tabular}

\section{Faktor Predisposisi Perilaku Penggunaan APD}

Pada faktor predisposisi perilaku penggunaan APD diperoleh hasil berdasarkan pengisian kuesioner oleh responden dengan distribusi pada Tabel 1.

\section{Faktor Pendukung Perilaku Penggunaan APD}

Faktor pendukung yang diteliti dan diduga memengaruhi perilaku penggunaan APD pada petugas laboratorium Rumah Sakit PHC Surabaya adalah ketersediaan APD. Berdasarkan hasil kuesioner didapatkan bahwa sebagian besar petugas laboratorium Rumah Sakit PHC Surabaya, yakni 9 responden $(60 \%)$ menyatakan bahwa APD yang tersedia adalah jas laboratorium, sarung tangan dan masker (tersedia sebagian). Enam responden (40\%) menyatakan bahwa APD yang tersedia jas laboratorium, sarung tangan, masker dan sepatu tertutup (tersedia lengkap).

\section{Faktor Pendorong Perilaku Penggunaan APD}

Faktor pendorong perilaku penggunaan APD menurut persepsi responden diperoleh hasil pada Tabel 2.

\section{Perilaku Penggunaan APD}

Perilaku penggunaan APD dikategorikan menjadi baik, kurang baik dan buruk. Berdasarkan hasil penelitian, diperoleh informasi bahwa 6 responden (40\%) mempunyai perilaku penggunaan APD baik sedangkan 9 responden (60\%) mempunyai perilaku penggunaan APD kurang baik. APD

Tabel 2. Faktor Pendorong Perilaku Penggunaan APD menurut persepsi Responden

\begin{tabular}{lcc}
\hline Faktor Pendorong & $\begin{array}{c}\text { Jumlah } \\
\text { (orang) }\end{array}$ & $\begin{array}{c}\text { Persentase } \\
(\%)\end{array}$ \\
\hline Peraturan/kebijakan & & \\
$\quad$ Ada & 15 & 100 \\
\hline Sosialisasi & & \\
$\quad$ Ada & 13 & 86,7 \\
$\quad$ Tidak ada & 2 & 13,3 \\
\hline Pengawasan & & \\
$\quad$ Ada & 11 & 73,3 \\
$\quad$ Tidak ada & 4 & 26,7 \\
\hline Pemberian Penghargaan & & \\
$\quad$ Ada & 15 & 100 \\
\hline Pemberian Sanksi & & \\
$\quad$ Ada & 12 & 80 \\
$\quad$ Tidak ada & 3 & 20 \\
\hline
\end{tabular}


Tabel 3. Tabulasi Silang Faktor Predisposisi dengan Perilaku Penggunaan APD

\begin{tabular}{crrr}
\hline $\begin{array}{c}\text { Faktor } \\
\text { Predisposisi }\end{array}$ & \multicolumn{2}{c}{ Perilaku } & \\
\cline { 2 - 3 } & \multicolumn{1}{c}{ Baik } & \multicolumn{1}{c}{ Kurang } & \\
\cline { 2 - 3 } Usia & & & \\
$<31$ tahun & $4(50 \%)$ & $4(50 \%)$ & $8(100 \%)$ \\
$31-40$ tahun & $2(33,3 \%)$ & $4(66,7 \%)$ & $6(100 \%)$ \\
$>40$ tahun & $0(0 \%)$ & $1(100 \%)$ & $1(100 \%)$ \\
\hline Jenis Kelamin & & & \\
Laki-laki & $0(0 \%)$ & $4(100 \%)$ & $4(100 \%)$ \\
Perempuan & $6(54,5 \%)$ & $5(45,5 \%)$ & $11(100 \%)$ \\
\hline Masa Kerja & & & \\
$<5$ tahun & $3(60 \%)$ & $2(40 \%)$ & $5(100 \%)$ \\
5-10 tahun & $3(42,9 \%)$ & $4(57,1 \%)$ & $7(100 \%)$ \\
$>10$ tahun & $0(0 \%)$ & $3(100 \%)$ & $3(100 \%)$ \\
\hline Tingkat & & & \\
Pendidikan & & & \\
Diploma & $5(41,7 \%)$ & $7(58,3 \%)$ & $12(100 \%)$ \\
Sarjana & $1(33,3 \%)$ & $2(66,7 \%)$ & $3(100 \%)$ \\
\hline Pengetahuan & & & \\
Baik & $5(38,5 \%)$ & $8(61,5 \%)$ & $13(100 \%)$ \\
Cukup & $1(50 \%)$ & $1(50 \%)$ & $2(100 \%)$ \\
\hline Sikap & & & \\
Baik & $3(37,5 \%)$ & $5(62,5 \%)$ & $8(100 \%)$ \\
Cukup & $3(42,9 \%)$ & $4(57,1 \%)$ & $7(100 \%)$ \\
\hline
\end{tabular}

yang sering digunakan oleh petugas laboratorium adalah jas laboratorium dan sarung tangan sedangkan masker jarang digunakan oleh petugas laboratorium.

\section{Hubungan Faktor Predisposisi dengan Perilaku Penggunaan APD}

Hubungan faktor predisposisi dengan perilaku penggunaan APD berdasarkan tabulasi silang antar variabel pada Tabel 3 .

\section{Hubungan Faktor Pendukung dengan Perilaku Penggunaan APD}

Hubungan faktor pendukung, yakni ketersediaan APD dengan perilaku penggunaan APD berdasarkan tabulasi silang antar variabel pada Tabel 4.

\section{Hubungan Faktor Pendorong dengan Perilaku Penggunaan APD}

Hubungan faktor pendorong dengan perilaku penggunaan APD berdasarkan tabulasi silang antar variabel pada Tabel 5 .
Tabel 4. Tabulasi Silang Ketersediaan APD dengan Perilaku Penggunaan APD

\begin{tabular}{lrrr}
\hline \multirow{2}{*}{$\begin{array}{c}\text { Ketersediaan } \\
\text { APD }\end{array}$} & \multicolumn{2}{c}{ Perilaku } & \\
\cline { 2 - 3 } & \multicolumn{1}{c}{ Penggunaan APD } & \multirow{2}{*}{ Total } \\
\hline Tersedia lengkap & $3(50 \%)$ & \multicolumn{1}{c}{ Kurang } & \\
Tersedia sebagian & $3(33,3 \%)$ & $6(66,7 \%)$ & $6(100 \%)$ \\
\hline
\end{tabular}

Tabel 5. Tabulasi Silang Faktor Pendorong dengan Perilaku Penggunaan APD

\begin{tabular}{|c|c|c|c|}
\hline \multirow{2}{*}{$\begin{array}{c}\text { Faktor } \\
\text { Pendorong }\end{array}$} & \multicolumn{2}{|c|}{$\begin{array}{c}\text { Perilaku Penggunaan } \\
\text { APD }\end{array}$} & \multirow[t]{2}{*}{ Total } \\
\hline & Baik & Kurang & \\
\hline \multicolumn{4}{|l|}{ Sosialisasi } \\
\hline a. Ada & $5(38,3 \%)$ & $8(61,5 \%)$ & $13(100 \%)$ \\
\hline b. Tidak ada & $1(50 \%)$ & $1(50 \%)$ & $2(100 \%)$ \\
\hline \multicolumn{4}{|l|}{ Pengawasan } \\
\hline a. Ada & $4(36,4 \%)$ & $7(63,6 \%)$ & $11(100 \%)$ \\
\hline b. Tidak ada & $2(50 \%)$ & $2(50 \%)$ & $4(100 \%)$ \\
\hline \multicolumn{4}{|l|}{ Pemberian } \\
\hline \multicolumn{4}{|l|}{ Sanksi } \\
\hline a. Ada & $1(33,3 \%)$ & $2(66,7 \%)$ & $3(100 \%)$ \\
\hline b. Tidak ada & $5(41,7 \%)$ & $7(58,3 \%)$ & $12(100 \%)$ \\
\hline
\end{tabular}

\section{PEMBAHASAN}

\section{Faktor Predisposisi Perilaku Penggunaan APD}

Karakteristik responden yang dijadikan variabel dalam penelitian ini adalah usia, jenis kelamin, masa kerja dan tingkat pendidikan. Berdasarkan hasil penelitian diketahui bahwa petugas laboratorium Rumah Sakit PHC Surabaya cukup beragam mulai dari 25 tahun hingga 45 tahun. Secara persentase kelompok usia paling banyak adalah kelompok usia $<31$ tahun $(53,3 \%)$ sedangkan kelompok usia paling sedikit adalah kelompok usia $>40$ tahun $(6,7 \%)$. Usia antara 20-30 tahun merupakan usia yang produktif dalam bekerja karena masih memiliki kesegaran jasmani yang prima. Kesegaran jasmani hal penting yang mampu menunjang produktivitas seseorang dalam bekerja.

Secara gender (jenis kelamin), petugas laboratorium Rumah Sakit PHC Surabaya didominasi oleh petugas perempuan $(73,3 \%)$. Lakilaki dan perempuan mempunyai perbedaan baik dari kemampuan fisik maupun otot. Secara umum, perempuan hanya memiliki $2 / 3$ kemampuan fisik atau otot laki-laki. Namun, dalam beberapa hal tertentu wanita lebih teliti jika dibandingkan dengan laki-laki. 
Secara persentase masa kerja petugas laboratorium Rumah Sakit PHC Surabaya paling banyak adalah masa kerja 5-10 tahun (46,7\%) sedangkan masa kerja paling sedikit adalah masa kerja $>10$ tahun $(20 \%)$. Masa kerja terendah berdasarkan hasil pengisian kuesioner adalah 1 tahun, sedangkan masa kerja tertinggi adalah 15 tahun. Masa kerja seorang tenaga kerja berhubungan dengan pengalaman kerja, pengetahuan dan keterampilan kerja yang dimilikinya. Semakin lama seseorang bekerja, maka akan semakin banyak pengalaman kerja, pengetahuan dan keterampilan kerja yang didapatnya.

Tingkat pendidikan formal yang telah didapatkan oleh sebagian besar petugas laboratorium Rumah Sakit PHC Surabaya adalah tingkat pendidikan diploma, yakni D3 analis kesehatan (80\%). Minat studi ini sangat berperan pada pekerjaan yang sedang mereka geluti sekarang ini. Notoatmodjo (2012) mengemukakan bahwa semakin tinggi pendidikan, maka semakin besar pula kemungkinan seseorang untuk memperoleh informasi. Semakin banyak informasi yang didapatkan, maka akan semakin besar pula pengetahuan yang dimiliki.

Pengetahuan menurut Notoatmodjo (2012) merupakan hasil dari tahu, umumnya diperoleh setelah seseorang telah menggunakan panca inderanya. Berdasarkan hasil penelitian diketahui bahwa sebagian besar $(86,7 \%)$ petugas laboratorium Rumah Sakit PHC Surabaya telah memiliki pengetahuan yang baik. Tidak ada satu petugas laboratorium pun yang mempunyai pengetahuan buruk atau bahkan sangat buruk. Pengetahuan yang baik ini dapat diperoleh melalui berbagai macam sumber, salah satunya melalui pendidikan formal yang telah diselesaikan.

Selain melalui pendidikan formal, pengetahuan yang baik ini juga dapat diperoleh melalui peningkatan mutu SDM yang ada pada Rumah Sakit PHC Surabaya. Rumah Sakit PHC Surabaya sendiri melalui bagian diklat (pendidikan dan latihan) secara rutin sering mengadakan pelatihan bagi tenaga kerjanya untuk meningkatkan mutu SDMnya. Selain pelatihan, khusus mengenai APD, ketua K3RS setiap 3 bulan sekali rutin mensosialisasikan pentingnya penggunaan APD kepada seluruh tenaga kerja rumah sakit, termasuk petugas laboratorium. Hal tersebut telah sesuai dengan program K3RS, khususnya dalam upaya pengembangan SDM K3.

Sikap menurut Maramis (2006) merupakan predisposisi umum untuk berespons atau bertindak secara positif atau negatif terhadap suatu objek atau orang disertai emosi positif atau negatif. Hasil dari pengisian kuesioner menunjukkan bahwa proporsi yang hampir sama antara petugas laboratorium Rumah Sakit PHC Surabaya yang mempunyai sikap baik $(53,3 \%)$ dan petugas laboratorium dengan sikap yang cukup (46,7\%). Petugas laboratorium dengan sikap yang baik sedikit lebih banyak jika dibandingkan dengan petugas laboratorium dengan sikap yang cukup.

Sikap merupakan faktor predisposisi yang ada dalam diri individu. Meskipun demikian, sikap dalam diri seseorang dibentuk atau ditentukan oleh lingkungan sekitar. Sikap lingkungan kerja yang positif (mendukung) terhadap penggunaan APD, sedikit banyak dapat mengubah sikap seseorang yang awalnya negatif (tidak mendukung) terhadap penggunaan APD menjadi positif (mendukung) terhadap penggunaan APD. Sikap juga dapat dipengaruhi oleh pengetahuan dan informasi yang telah diperoleh. Rumah Sakit PHC Surabaya rutin memberikan pengetahuan dan informasi baru kepada seluruh tenaga kerja, termasuk petugas laboratorium melalui pelatihan yang diselenggarakan oleh bagian diklat Rumah Sakit PHC Surabaya dan sosialisasi rutin oleh ketua K3RS mengenai penggunaan APD.

\section{Faktor Pendukung Perilaku Penggunaan APD}

Hasil pengisian kuesioner menunjukkan bahwa sebagian besar $(60 \%)$ petugas laboratorium Rumah Sakit PHC Surabaya berpendapat bahwa APD yang tersedia hanya jas laboratorium, sarung tangan dan masker (tersedia sebagian). Lampiran Permenkes Nomor 411 Tahun 2010 menyebutkan bahwa laboratorium harus menyediakan dan senantiasa mencukupi kebutuhan APD petugasnya, baik jenis maupun jumlahnya. APD yang disebutkan dalam perundangan tersebut adalah sarung tangan sesuai kebutuhan, masker sesuai kebutuhan, jas laboratorium sesuai jumlah petugas dan alas kaki sesuai kebutuhan.

Tersedianya APD ini telah memenuhi salah satu program K3RS, yakni dalam hal pengembangan manajemen tanggap darurat sebagaimana yang tercantum dalam lampiran Kepmenkes Nomor 1087 Tahun 2010. Tersedianya APD juga telah memenuhi program K3RS, yakni pengembangan manajemen tanggap darurat dan Permenakertras (Peraturan Menteri Tenaga Kerja dan Transmigrasi Nomor 8 Tahun 2010 pasal 1).

Berdasarkan jumlah tiap APD, baik jas laboratorium, sarung tangan maupun masker telah memenuhi kebutuhan seluruh petugas laboratorium 
Rumah Sakit PHC Surabaya. Jumlah jas laboratorium tersedia telah melebihi jumlah petugas laboratorium yang bertugas. Sarung tangan dan masker yang telah disediakan pun juga mencukupi (masing-masing \pm 1 box) dan layak pakai. Ketersediaan jumlah jas laboratorium, sarung tangan dan masker ini telah sesuai dengan Permenkes Nomor 411 Tahun 2010. Namun demikian, secara keseluruhan, terutama jika ditinjau dari jenis APD yang telah disediakan, APD yang telah disediakan oleh Rumah Sakit PHC Surabaya masih belum memenuhi Permenkes Nomor 411 Tahun 2010 karena belum memenuhi salah satu kebutuhan APD petugas laboratorium, yakni alas kaki.

\section{Faktor Pendorong Perilaku Penggunaan APD}

Seluruh responden (100\%) berdasarkan pengisian kuesioner, menyatakan bahwa telah ada peraturan/kebijakan mengenai penggunaan APD. Berdasarkan hasil wawancara dengan ketua K3RS diperoleh informasi bahwa Rumah Sakit PHC Surabaya melalui surat dari direktur rumah sakit telah menetapkan peraturan/kebijakan mengenai penggunaan APD bagi seluruh tenaga kerja rumah sakit, termasuk petugas laboratorium. Surat dari direktur rumah sakit ini ditindaklanjuti melalui SOP pada tiap unit dalam rumah sakit, termasuk SOP pada unit laboratorium.

Sosialisasi sebagaimana tertulis dalam Wikipedia (2014) merupakan sebuah proses penanaman atau transfer kebiasaan atau nilai dan aturan dari satu generasi ke generasi lainnya dalam sebuah kelompok masyarakat. Hasil kuesioner menunjukkan bahwa sebagian besar (86,7\%) petugas laboratorium Rumah Sakit PHC Surabaya berpendapat bahwa telah ada sosialisasi mengenai penggunaan APD. Sosialisasi menurut Arindra (2012) dapat dilakukan secara lisan, misalnya briefing, penyuluhan dan pelatihan, maupun secara tertulis, misalnya penempelan poster. Berdasarkan hasil wawancara oleh ketua K3RS diperoleh informasi bahwa sosialisasi secara dilakukan secara rutin 3 bulan sekali oleh ketua K3RS kepada tiap-tiap unit yang ada di Rumah Sakit PHC Surabaya.

Sosialisasi melalui tulisan dilakukan melalui penempelan SOP dan beberapa tulisan yang mengingatkan mengenai penggunaan APD. Namun demikian, sosialisasi melalui tulisan yang sudah dilakukan oleh Rumah Sakit PHC Surabaya menurut peneliti masih belum maksimal. Hal ini dikarenakan beberapa SOP ditempel pada tempat yang tidak strategis (sulit dijangkau mata) serta desain tulisan berisi peringatan yang ditempel tidak menarik perhatian (polos, tidak ada desain sama sekali). Oleh karena itu, disarankan kepada manajemen Rumah Sakit PHC Surabaya untuk memperhatikan lokasi penempelan SOP serta memperbaiki desain tulisan agar lebih menarik perhatian petugas untuk membacanya.

Pengawasan menurut Kusuma (2004) merupakan kegiatan rutin dalam bentuk observasi harian terhadap penggunaan APD yang dilakukan oleh pengawas yang ditunjuk untuk melakukan pemantauan terhadap pelaksanaan kerja bawahannya dan memastikan bahwa mereka terus menerus menggunakan APD secara benar. Sebagian besar $(73,3 \%)$ petugas laboratorium Rumah Sakit PHC Surabaya berpendapat bahwa telah ada pengawasan mengenai penggunaan APD. Menurut hasil wawancara dengan ketua K3RS, pengawasan mengenai penggunaan APD pada petugas laboratorium dilakukan oleh penanggung jawab laboratorium itu sendiri.

Penanggung jawab laboratorium nantinya menyampaikan hasil pengawasan penggunaan APD melalui 2 cara, yakni laporan langsung kepada sekretaris K3RS atau melalui pengisian form pada folder K3RS melalui PC (personal computer) yang telah diintegrasikan oleh bagian sistem informasi Rumah Sakit PHC Surabaya. Pengawasan atau pemantauan mengenai penggunaan APD merupakan salah satu elemen dalam pengumpulan, pengolahan, dokumentasi data dan pelaporan kegiatan K3RS sebagaimana tercantum dalam lampiran Kepmenkes Nomor 1087 Tahun 2010.

Seluruh responden $(100 \%)$ berdasarkan pengisian kuesioner, tidak mengetahui mengenai mekanisme mengenai pemberian penghargaan yang diberikan bagi petugas laboratorium yang mempunyai perilaku penggunaan APD baik. Berdasarkan hasil wawancara dengan ketua K3RS, Rumah Sakit PHC Surabaya pada dasarnya telah mempunyai mekanisme pemberian penghargaan bagi petugas laboratorium yang mempunyai perilaku penggunaan APD yang baik, namun mekanisme pemberian hadiah tersebut dijadikan satu dengan patient safety, sehingga tenaga kesehatan, termasuk petugas laboratorium Rumah Sakit PHC Surabaya kemungkinan besar tidak mengetahuinya.

Pemberian sanksi dalam Kepmenkes Nomor 1087 Tahun 2010 disebutkan sebagai pemberian hukuman (punishment) merupakan salah satu elemen dalam program pendidikan, pelatihan dan pengembangan SDM K3. Hasil kuesioner 
menginformasikan bahwa sebagian besar $(80 \%)$ responden tidak mengetahui adanya pemberian sanksi yang diberlakukan bagi petugas laboratorium yang mempunyai perilaku penggunaan APD kurang baik atau bahkan buruk. Berdasarkan hasil wawancara dengan ketua K3RS diketahui bahwa pemberian sanksi sepenuhnya adalah hak dari manajer atau penanggung jawab unit masingmasing.

\section{Perilaku Penggunaan APD}

Berdasarkan hasil observasi terhadap petugas laboratorium Rumah Sakit PHC Surabaya diketahui bahwa sebagian besar $(60 \%)$ memiliki perilaku penggunaan APD yang kurang baik sedangkan $40 \%$ petugas laboratorium mempunyai perilaku penggunaan APD yang baik. Perilaku penggunaan APD dinilai berdasarkan jenis APD yang selalu digunakan oleh petugas laboratorium. Sebagian besar laboratorium mempunyai perilaku baik dalam penggunaan jas laboratorium dan sarung tangan (sering atau bahkan selalu digunakan) dan mempunyai perilaku kurang baik dalam penggunaan masker (jarang atau bahkan tidak pernah digunakan.

Berdasarkan perbedaan shift kerja, petugas laboratorium yang bekerja pada shift malam memiliki perilaku penggunaan APD yang sedikit kurang baik jika dibandingkan dengan 2 shift lainnya. Petugas laboratorium shift malam beberapa kali terlihat hanya menggunakan alas kaki terbuka/ sandal. Hal ini mungkin disebabkan karena pada shift malam beban kerja tidak terlalu banyak dan tidak ada pengawasan dari penanggung jawab unit laboratorium.

\section{Hubungan Faktor Predisposisi Perilaku Penggunaan APD}

Berdasarkan tabel 3 diketahui bahwa proporsi petugas laboratorium Rumah Sakit PHC Surabaya pada kelompok usia $<31$ tahun mempunyai perilaku penggunaan APD baik yang paling tinggi (50\%) dan petugas laboratorium pada kelompok usia $>40$ tahun mempunyai perilaku penggunaan APD baik yang paling rendah $(0 \%)$. Hal ini menunjukkan bahwa semakin muda usia petugas laboratorium Rumah Sakit PHC Surabaya maka kecenderungan untuk mempunyai perilaku penggunaan APD baik akan semakin besar. Sebaliknya, semakin tua usia petugas laboratorium maka akan semakin buruk perilaku penggunaan APD-nya.
Petugas laboratorium Rumah Sakit PHC Surabaya yang masih muda umumnya merupakan pekerja baru dengan masa kerja rendah. Petugas laboratorium baru umumnya masih menunjukkan perilaku yang baik dengan harapan apabila perilaku dan kinerjanya baik, maka pihak manajemen Rumah Sakit PHC Surabaya akan memperpanjang kontrak kerjanya. Adapun kecenderungan perilaku penggunaan APD buruk pada petugas laboratorium dengan usia lebih tua, kemungkinan disebabkan karena adanya perasaan "aman" karena dalam kurun waktu tertentu pihak manajemen rumah sakit selalu menggunakan jasanya sebagai petugas laboratorium rumah sakit tersebut.

Berdasarkan jenis kelamin, diketahui bahwa tidak ada satu pun $(0 \%)$ petugas laboratorium Rumah Sakit PHC Surabaya yang mempunyai perilaku penggunaan APD baik. Adapun proporsi petugas laboratorium perempuan yang mempunyai perilaku penggunaan APD baik sebesar 54,5\%. Berdasarkan data tersebut, dapat disimpulkan bahwa petugas laboratorium Rumah Sakit PHC Surabaya cenderung mempunyai perilaku penggunaan APD yang baik jika dibandingkan dengan petugas laboratorium laki-laki.

Jenis pekerjaan yang ada pada unit laboratorium pada dasarnya membutuhkan ketelitian dan ketelatenan yang tinggi. Perempuan umumnya mempunyai sifat tersebut, yakni lebih teliti, lebih sabar dan lebih telaten jika dibandingkan dengan laki-laki. Lebih tinggi yang notabene lebih dimiliki perempuan. Penggunaan APD, terutama sarung tangan dirasa dapat mengganggu kenyamanan saat melakukan pekerjaan dengan tingkat ketelitian tinggi. Terganggunya kenyamanan saat melakukan aktivitas dengan ketelitian tinggi inilah yang diduga menjadi faktor penyebab petugas laboratorium lakilaki enggan menggunakannya.

Secara teoritis, seseorang dengan masa kerja tinggi akan lebih memahami pekerjaannya, termasuk memahami upaya pencegahan yang harusnya dilakukan agar terhindar dari bahaya yang tidak diinginkan. Hal tersebut nampaknya tidak sejalan dengan hasil penelitian yang telah didapat. Tabel 3 justru menunjukkan bahwa proporsi petugas laboratorium Rumah Sakit PHC Surabaya dengan masa kerja $<5$ tahun mempunyai perilaku penggunaan APD baik yang paling tinggi (60\%) sedangkan petugas laboratorium dengan masa kerja $>10$ tahun mempunyai perilaku penggunaan APD baik yang paling rendah $(0 \%)$. Semakin rendah masa kerja petugas laboratorium Rumah Sakit PHC 
Surabaya maka kecenderungan untuk mempunyai perilaku penggunaan APD yang baik akan semakin besar.

Hal ini dikarenakan petugas laboratorium dengan masa kerja yang rendah $(<5$ tahun $)$ merupakan karyawan baru dalam Rumah Sakit PHC Surabaya yang umumnya lebih patuh kepada peraturan/kebijakan yang telah berlaku. Selama masa kontrak awal 2 tahun, apabila hasil kerjanya tidak memuaskan, maka kemungkinan petugas tersebut tidak akan digunakan lagi jasanya. Sebaliknya, apabila dalam masa kontrak awal 2 tahun, petugas laboratorium tersebut mempunyai kinerja yang bagus dan mempunyai perilaku yang baik, maka kemungkinan besar akan digunakan lagi jasanya dan diperpanjang masa kontraknya.

Berdasarkan tabel 3, diketahui bahwa proporsi petugas laboratorium Rumah Sakit PHC Surabaya dengan tingkat pendidikan diploma yang mempunyai perilaku penggunaan APD baik, lebih besar (41,7\%) dibanding petugas laboratorium dengan tingkat pendidikan sarjana $(33,3 \%)$. Tingginya tingkat pendidikan tidak diikuti dengan baiknya perilaku seseorang dalam menggunakan APD. Hal tersebut menunjukkan bahwa tinggi atau rendah pendidikan petugas laboratorium Rumah Sakit PHC Surabaya tidak begitu berpengaruh pada baiknya perilaku penggunaan APD. Seseorang dengan pendidikan tinggi belum tentu mempunyai perilaku penggunaan APD yang baik, begitu juga sebaliknya.

Pendidikan merupakan salah wadah bagi seseorang untuk mendapatkan pengetahuan. Pengetahuan dan informasi merupakan dasar seseorang dalam bersikap dan bertindak. Namun demikian, pengetahuan yang baik, apabila tidak diimbangi dengan sikap dan keinginan untuk bertindak tidak akan ada artinya.

Tabel 3 menunjukkan bahwa proporsi petugas laboratorium Rumah Sakit PHC Surabaya dengan pengetahuan cukup yang mempunyai perilaku penggunaan APD baik justru lebih besar (50\%) dibanding petugas laboratorium dengan pengetahuan baik $(38,5 \%)$. Semakin baik pengetahuan yang dimiliki oleh petugas laboratorium Rumah Sakit PHC Surabaya maka semakin buruk perilaku penggunaan APD-nya. Hubungan ini merupakan hubungan yang bersifat negatif, yakni hubungan yang menunjukkan bahwa peningkatan variabel bebas tertentu justru akan menyebabkan penurunan pada variabel tergantung.

Hasil tabulasi silang antara variabel pengetahuan dan variabel perilaku penggunaan APD diketahui bahwa telah terjadi inkonsistenan antara pengetahuan dan tindakan, yang umumnya dikenal sebagai disonansi kognitif. Maramis (2006) menyebutkan bahwa disonansi kognitif terjadi bila dua dari kognisi itu secara "psikologis" inkonsisten. Pada dasarnya hampir seluruh petugas laboratorium telah memiliki tingkat pengetahuan yang baik, namun tidak diimbangi dengan perilaku penggunaan APD yang baik pula. Pengetahuan yang baik ini apabila tidak diimbangi dengan sikap dan niat yang baik maka tidak akan menghasilkan perilaku penggunaan APD yang baik.

Allport dalam Yuwono, dkk (2005) mendefinisikan sikap sebagai suatu keadaan mental dan neural yang terjaga, diorganisasikan melalui pengalaman, merupakan respons individual terhadap suatu objek dan situasi terkait. Tabel 3, menunjukkan bahwa proporsi petugas laboratorium Rumah Sakit PHC Surabaya dengan sikap kurang yang mempunyai perilaku penggunaan APD baik sedikit lebih besar (42,9\%) dibandingkan petugas laboratorium dengan sikap baik $(37,5 \%)$. Premis yang diperoleh serupa dengan premis yang ada pada pengetahuan dan perilaku penggunaan APD. Semakin baik sikap seseorang, maka kecenderungan untuk mempunyai perilaku penggunaan APD yang baik akan semakin rendah.

Sebagian besar pendapat menyatakan bahwa sikap seseorang dapat memengaruhi perilaku yang akan dilakukan. Richard LaPiere dalam Suryanto, dkk (2012) membuktikan pendapat yang berbeda bahwa hubungan antara sikap dan perilaku tidak selalu bersifat positif. Suryanto, dkk (2012) menyebutkan bahwa sikap merupakan salah satu determinan perilaku sosial, tetapi tetap ada determinan lainnya yang harus diperhatikan. Inkonsistensi antara sikap dan tindakan petugas laboratorium Rumah Sakit PHC Surabaya disebabkan karena tidak adanya intensi atau minat dari petugas laboratorium itu sendiri.

\section{Hubungan Faktor Pendukung Perilaku Penggunaan APD}

Faktor pendukung dalam penelitian ini adalah ketersediaan APD di unit laboratorium Rumah Sakit PHC Surabaya. Sebagian besar (60\%) petugas laboratorium menyatakan bahwa APD yang disediakan sebagian. Hal tersebut dikarenakan alas kaki/sepatu yang digunakan oleh petugas laboratorium Rumah Sakit PHC saat ini merupakan alas kaki/sepatu tertutup milik masing-masing. Secara proporsi, petugas 
laboratorium Rumah Sakit PHC Surabaya yang berpendapat bahwa APD tersedia lengkap, yang mempunyai perilaku penggunaan APD baik, lebih besar $(50 \%)$ dibandingkan petugas laboratorium yang berpendapat bahwa APD tersedia sebagian $(33,3 \%)$.

Semakin petugas laboratorium Rumah Sakit PHC Surabaya merasa bahwa APD yang disediakan telah lengkap, maka proporsi untuk mempunyai perilaku penggunaan APD yang baik, akan semakin besar. Notoatmodjo (2012) menyebutkan bahwa sarana dan prasarana merupakan faktor pendukung dari suatu tindakan. Dalam perilaku penggunaan APD, jika APD itu sendiri tidak tersedia, maka perilaku penggunaan APD akan buruk, karena tidak ada APD yang dapat digunakan. Meski APD yang disediakan sudah cukup lengkap, yakni jas laboratorium, sarung tangan dan masker, namun tidak semua jenis APD selalu digunakan oleh petugas laboratorium Rumah Sakit PHC Surabaya.

\section{Hubungan Faktor Pendorong Perilaku Penggunaan APD}

Secara proporsi, petugas laboratorium Rumah Sakit PHC Surabaya yang tidak mengetahui adanya sosialisasi mempunyai perilaku penggunaan APD baik, lebih besar (50\%) dibandingkan dengan petugas laboratorium yang berpendapat bahwa ada sosialisasi $(38,3 \%)$. Semakin petugas laboratorium Rumah Sakit PHC Surabaya tidak mengetahui adanya sosialisasi maka kecenderungan untuk mempunyai perilaku penggunaan APD yang baik akan semakin besar.

Hasil tabulasi silang menunjukkan bahwa perilaku penggunaan APD yang baik semata-mata tidak dipengaruhi karena adanya sosialisasi. Petugas laboratorium yang memiliki perilaku penggunaan APD baik pada dasarnya telah memiliki intensi untuk berperilaku baik (tidak dipengaruhi oleh adanya sosialisasi), karena tanpa adanya intense, sebuah perilaku tidak akan dapat terwujud.

Petugas laboratorium Rumah Sakit PHC Surabaya yang tidak mengetahui adanya pengawasan, proporsi untuk mempunyai perilaku penggunaan APD baik justru lebih besar (50\%) dibandingkan dengan petugas laboratorium yang berpendapat bahwa ada pengawasan (36,4\%). Semakin petugas laboratorium Rumah Sakit PHC Surabaya tidak mengetahui adanya pengawasan, maka perilaku penggunaan APD-nya akan semakin baik.

Hal tersebut menunjukkan bahwa pengawasan yang ada tidak berpengaruh pada perilaku penggunaan APD pada petugas laboratorium Rumah Sakit PHC Surabaya. Petugas laboratorium Rumah Sakit PHC Surabaya yang mempunyai perilaku penggunaan APD baik pada dasarnya telah mempunyai intensi untuk berperilaku baik, tidak semata-mata dikarenakan adanya pengawasan oleh penanggung jawab laboratorium. Terlebih lagi, pengawasan penggunaan APD yang ada pada unit laboratorium dirasa masih belum maksimal sehingga belum bisa mengupayakan terjadi peningkatan perilaku penggunaan APD yang baik.

Hasil tabulasi silang juga menunjukkan bahwa petugas laboratorium Rumah Sakit PHC Surabaya yang tidak mengetahui adanya pemberian sanksi, proporsi untuk mempunyai perilaku penggunaan APD baik, sedikit lebih besar $(41,7 \%)$ dibandingkan dengan petugas laboratorium yang berpendapat bahwa ada pemberian sanksi $(33,3 \%)$. Semakin petugas laboratorium Rumah Sakit PHC Surabaya tidak mengetahui adanya pemberian sanksi, maka kecenderungan untuk mempunyai perilaku penggunaan APD baik akan semakin besar. Petugas laboratorium Rumah Sakit PHC Surabaya yang mempunyai perilaku penggunaan APD baik sematamata tidak disebabkan karena adanya pemberian sanksi, melainkan karena telah adanya intensi dari masing-masing individu.

Hal tersebut menunjukkan bahwa pengawasan yang ada tidak berpengaruh pada perilaku penggunaan APD pada petugas laboratorium Rumah Sakit PHC Surabaya. Petugas laboratorium Rumah Sakit PHC Surabaya yang mempunyai perilaku penggunaan APD baik pada dasarnya telah mempunyai intensi untuk berperilaku baik, tidak semata-mata dikarenakan adanya pengawasan oleh penanggung jawab laboratorium. Terlebih lagi, pengawasan penggunaan APD yang ada pada unit laboratorium dirasa masih belum maksimal sehingga belum bisa mengupayakan terjadi peningkatan perilaku penggunaan APD yang baik.

Hasil tabulasi silang juga menunjukkan bahwa petugas laboratorium Rumah Sakit PHC Surabaya yang tidak mengetahui adanya pemberian sanksi, proporsi untuk mempunyai perilaku penggunaan APD baik, sedikit lebih besar (41,7\%) dibandingkan dengan petugas laboratorium yang berpendapat bahwa ada pemberian sanksi $(33,3 \%)$. Semakin petugas laboratorium Rumah Sakit PHC Surabaya tidak mengetahui adanya pemberian sanksi, maka kecenderungan untuk mempunyai perilaku penggunaan APD baik akan semakin besar. Petugas laboratorium Rumah Sakit PHC Surabaya yang 
mempunyai perilaku penggunaan APD baik sematamata tidak disebabkan karena adanya pemberian sanksi, melainkan karena telah adanya intensi dari masing-masing individu.

\section{SIMPULAN}

Sebagian besar $(53,3 \%)$ usia responden $<31$ tahun. Mayoritas $(73,3 \%)$ responden adalah perempuan. Sebagian besar responden telah bekerja $\geq 5$ tahun. Sebagian besar $(80 \%)$ responden mempunyai tingkat pendidikan diploma. Sebagian besar $(86,7 \%)$ responden mempunyai pengetahuan yang baik dan sebagian besar $(53,3 \%)$ responden mempunyai sikap yang baik.

Hanya $40 \%$ responden yang menyatakan bahwa APD yang tersedia adalah jas laboratorium, sarung tangan dan masker (APD tersedia sebagian).

Seluruh (100\%) responden menyatakan bahwa telah ada peraturan/kebijakan dan tidak ada pemberian penghargaan. Sebagian besar $(86,7 \%)$ responden menyatakan bahwa telah ada sosialisasi. Sebagian besar $(73,3 \%)$ responden menyatakan bahwa ada pengawasan. Sebagian besar $(80 \%)$ responden menyatakan bahwa tidak ada pemberian sanksi.

Sebagian besar $(60 \%)$ responden mempunyai perilaku penggunaan APD yang kurang baik sedangkan $40 \%$ responden lainnya mempunyai perilaku penggunaan APD yang baik.

\section{DAFTAR PUSTAKA}

Arindra, D. 2012. Pelaksanaan Sosialisasi dan Penggunaan APD (Alat Pelindung Diri) di PT. Japfa Comfeed Indonesia Tbk. Tugas Akhir. Surabaya: Fakultas Kesehatan Masyarakat Universitas Airlangga.

Jannah, N. 2009. Beberapa Faktor yang Berhubungan dengan Pemakaian Alat Pelindung Diri pada Pekerja Laboratorium Patologi Klinik RSUD Sidoarjo. Skripsi. Surabaya: Fakultas Kesehatan Masyarakat Universitas Airlangga.
Keputusan Menteri Kesehatan Republik Indonesia Nomor: 1087/MENKES/SK/VIII/2010. Standar Kesehatan dan Keselamatan Kerja di Rumah Sakit. Jakarta: Kementerian Kesehatan.

Kusuma, I. 2004. Faktor-Faktor yang Berhubungan dengan Penggunaan Alat Pelindung Diri (Hearing Protector) pada Pekerja Bagian Die Casting PT. X Tahun 2004. Tesis. Jakarta: Magister Keselamatan dan Kesehatan Kerja Fakultas Kesehatan Masyarakat Universitas Indonesia.

Maramis, W.F. 2006. Ilmu Perilaku dalam Pelayanan Kesehatan. Surabaya: Airlangga University Press.

Notoatmodjo, S. 2012. Metodologi Penelitian Kesehatan. Edisi Revisi. Jakarta: Rineka Cipta.

Notoatmodjo, S. 2012. Promosi Kesehatan dan Perilaku Kesehatan. Edisi Revisi. Jakarta: Rineka Cipta.

Peraturan Menteri Kesehatan Republik Indonesia Nomor 411/MENKES/PER/III/2010. Laboratorium Klinik. Jakarta: Kementerian Kesehatan.

Peraturan Menteri Tenaga Kerja dan Transmigrasi Republik Indonesia Nomor Per. 08/MEN/VII/2010. Alat Pelindung Diri. Jakarta: Kementerian Kesehatan.

Rahaju, P. 2011. Analisis Faktor Pemakaian Alat Pelindung Diri (APD) pada Petugas di Unit Pelayanan Laboratorium. 2 (2). 374-381.

Suryanto, dkk. 2012. Pengantar Psikologi Sosial. Surabaya: Airlangga University Press.

Undang-Undang Nomor 36 Tahun 2009. Kesehatan. Jakarta: Kementerian Kesehatan.

Wikipedia. Sosialisasi. http://id.wikipedia.org/wiki/ Sosialisasi (sitasi 25 Juni 2014).

Yuwono, dkk. 2005. Psikologi Industri dan Organisasi. Surabaya: Fakultas Psikologi Universitas Airlangga. 